Killing the Crime Novel: Martin Amis's Night Train, Genre and Literary Fiction Author(s): Will Norman

Source: Journal of Modern Literature, Vol. 35, No. 1, Re-assessing, Breaking, Transcending Genres (Fall 2011), pp. 37-59

Published by: Indiana University Press

Stable URL: https://www.jstor.org/stable/10.2979/jmodelite.35.1.37

JSTOR is a not-for-profit service that helps scholars, researchers, and students discover, use, and build upon a wide range of content in a trusted digital archive. We use information technology and tools to increase productivity and facilitate new forms of scholarship. For more information about JSTOR, please contact support@jstor.org.

Your use of the JSTOR archive indicates your acceptance of the Terms \& Conditions of Use, available at https://about.jstor.org/terms 


\title{
Killing the Crime Novel: Martin Amis's Night Train, Genre and Literary Fiction
}

\author{
Will Norman
}

University of Kent

This article explores the encounter between autonomous aesthetics, mass genre and the publishing category of literary fiction in Martin Amis's Night Train. Taking the confused critical response to the novel as a starting point, I argue that the novel confounded the conventions governing the writing, circulation and consumption of contemporary literary fiction. In analyzing the narrative and stylistic strategies Amis deploys in exploiting the conventions of crime writing, I give an account of the relationship between bigh autonomous aesthetics and mass genre that made Night Train inimical to the category of literary fiction. Putting Amis's term "postmodern decadence" to use as a way of conceptualizing this relationship historically, we are able to reorientate our sense of Amis's place in the cultural field and understand the set of factors that have determined his vexed reputation in contemporary literature.

Keywords: Martin Amis / genre / literary fiction / postmodernism / decadence

Now I'm a genre writer of a sort. I write literary fiction, which is like spy fiction or chick lit.

-John Updike ${ }^{1}$

p n 1994, Martin Amis's demand for an advance of half a million pounds for the publication of his novel The Information was leaked to the British press, resulting in widespread public vilification. Advances considerably more generous than this were, in fact, not unheard of among bestselling authors in the 1990s. As Peter Strauss, former editor at Picador, claimed at the time, the shock of Amis's impetuousness was closely related to his perceived highbrow status. Amis was no John Grisham: "Commerce and literature are still meant to be separate in England," he said. "If you're writing mass-market fiction, it doesn't matter your price: you can be as vulgar as you want in terms of money. But somehow it isn't the same for literary fiction" (qtd. in Lyall). While British literary establishment figures such as A.S. Byatt publically expressed their contempt, Sarah Lyall, writing a column on the London literary scene for the Nerw York Times, remarked that "The British reaction to the Amis affair mystified many Americans, who are well 
used to star authors, big egos and big money." Indeed, The Sunday Times went so far as to ask whether or not Amis was attempting to "transform himself into an honorary 'American' author" ("I'm looking for some money"). In fact, by the end of 1995 The Information had not earned much more than 10 percent of its advance (Todd 19). Nevertheless, the two boundaries set up and policed by the furor over its publication - those between "literary" and "mass-market" fiction, and between British and American literary culture - were to find expression and transgression in Amis next novel, Night Train (1997). In this work, Amis chose directly and explicitly to take up the challenges issued by the troubled reception of The Information. Night Train assumes the guise of a classic American genre, the hardboiled detective story, and a first-person narration in the American vernacular. Not only had Amis transformed himself into an "honorary 'American' author," he was also working with a mass genre.

My proposal in this article is to explore the implications of this transgressive encounter staged in and by Night Train, with the aim of reorientating our understanding of Amis's vexed location within literary history. As John Lanchester wrote in his review of Night Train for The New Yorker, despite being "a kind of lightening rod for feelings of envy and ill will," Amis was "the most admired, imitated and influential writer of the last twenty years" (81). This is an intriguingly fraught judgment, and one typical of the paradoxical accounts of Amis's reputation that have proliferated since. My argument will be that such contradictions are located in the author's relationship to mass genres and to the publishing category of literary fiction as it has developed over approximately the last thirty years. We will see that examination of Night Train reveals a disjunction between the marketing, design and institutional reception of Amis's work as literary fiction on one hand, and the author's own strategies of composition on the other. In the light of this analysis, Amis's work yields a negative critique of the category of literary fiction from within its own domain, in rendering visible the tensions and compromises necessary to its desire for legitimacy.

If a consensus exists on what is meant by the term "mass genres," then the term "literary fiction" presents greater challenges. Literary fiction is here understood not in the ahistorical sense of a particular way of dealing with language that is inherently "literary," as in the old Russian Formalist emphasis on "laying bare the device" or in Wellek and Warren's Theory of Literature. Rather, I use the term in the sense of a category comprising a set of publishing processes and practices which include not only the composition and editing of the book, but also its design, marketing and distribution, as well as, most distinctively, its relationships with particular institutions such as literary prizes and broadsheet reviews. ${ }^{2}$ Literary fiction, to use Bourdieu's terminology, is a category of legitimate culture in that it positions itself hierarchically within the cultural field in opposition to other categories - typically mass-market genre fiction. However, much has changed since Bourdieu's classic study of French culture and taste in the 1960s and '70s, not least of which his association of legitimate culture with a Kantian ideal of aesthetic disinterestedness. Literary fiction, as a contemporary category 
dominating British and American literary culture since the early 1980s, does not necessarily share the rarefied forms of aesthetic composition and appreciation that Bourdieu located as the sine non qua of cultural capital. My analysis must therefore take into account historical shifts within the cultural field that have introduced a distinction, however visible or veiled, between literary fiction and the notions of aesthetic autonomy and formal innovation that have conventionally been thought of as characteristic of the highbrow since Flaubert (one of Bourdieu's key points of reference). As John Updike said in 2006, albeit with his tongue in his cheek, "now I'm a genre writer of a sort. I write literary fiction, which is like spy fiction or chick lit" (Grossman). ${ }^{3}$ There is a suspicion existing in some quarters, then, that the claims literary fiction makes to cultural legitimacy are questionable, and there is room for a critique of the category as well as for an attempt on the part of autonomous experimentalism to reclaim its former, dominant position. This is the context in which I will be examining Night Train, beginning with the novel's confused reception in the broadsheet press and then analyzing the novel's narrative and stylistic negotiation of the cultural field.

\section{RECEPTION}

Broadsheet reviewing is, alongside the closely related practice of awarding literary prizes, probably the most distinctive feature of contemporary literary fiction. As Rachel Malik has argued, one of the difficulties raised by the category is the necessity for consistent endorsement by high-status cultural intermediaries whose judgment cannot be guaranteed or even predicted (729). Thus one clear indicator of Amis's uneasy relationship to the category has been the repeated problem of wildly varying reviews within "quality" newspapers, magazines and journals in the US and UK. While consumers of literary fiction typically seek the security of consistent evaluation across a range of cultural authorities, so as to orient their own readings, such guidance has been unavailable in relation to Amis's output. The low-water mark of Amis's critical reputation, Tibor Fischer's infamous review of Yellow Dog in 2003 ("[it] isn't bad as in not very good or slightly disappointing. It's not-knowing-where-to-look bad"), had yet to be reached when Night Train was reviewed in September 1997, and yet the novel produced a typically unpredictable range of responses.

One of the most common confusions in the US arose over whether or not Night Train should be understood as an anomalous exception within the otherwise highbrow Amis canon. Michiko Kakutani at The New York Times opted to separate it from his more substantial novels, represented by London Fields and The Information. Night Train was "a stylized replica of a hardboiled yarn" and its ending "a clever cop-out." In this case, then, the novel was presented as a genre holiday for a novelist needing a break from the hard work of writing highbrow fiction. It is important to note that in this case Amis was in no way criticized for his perceived choice-Kakutani evidently found it entirely justifiable, although necessitating a suspension of the typical standard of judgment offered to more serious work. 
Geoffrey O'Brien, however, writing for New Republic, remained ambivalent, asking whether Night Train was "a case of the Serious Novelist moonlighting as Pop Entertainer, or disguising himself as Pop Entertainer the better to carry out some ulterior scheme" (32). The review is inconclusive on this question, which itself puts the entire category of literary fiction under threat: if its practice becomes an "ulterior scheme," unrecognizable even to cultural intermediaries, then what chance have its general readers in distinguishing it from its mass-genre rivals?

O'Brien's anxiety is palpable: the novel is guilty of withholding the baser narrative pleasures associated with detective fiction, and yet, due to its stylized voice, bars access to authenticity and realism too. In Natasha Walter's review for The Guardian in the UK, by contrast, there was no question of covert literariness being smuggled into Night Train. Walter judged it confidently a failed detective novel, in which those features arousing suspicion in the US, such as stylized voice, were simply inadequacies. Amis's dialogue, for instance, "keeps slipping into flat rhythms that have been culled from American screen cops." The possibility that such intertextualities may play an intentional part in the novelist's objectives is not considered here. We can add that such evaluation of literary style provides a particularly acute example of the kinds of unpredictable judgments that literary fiction relies upon (other critics, such as James Wood, found praise for the same rhythms that Walter finds dull). From this perspective, we gain an insight into the precariousness with which the category operates, using as prestige indicators precisely those factors least likely to attract consensus.

The most vociferous critics of Nigbt Train, John Updike and Anita Brookner, attacked Amis from scarcely more sophisticated positions. A British novelist, Brookner won the 1984 Booker Prize and has therefore a particular claim on the kind of cultural authority required of literary endorsement. In her review in The Spectator, she sustained her critique on the grounds that Amis was trying to write a Chandleresque thriller but lacked the requisite talents. "The voice," she wrote, "sets out to celebrate the demotic but ... ends up so out of hand that it is experienced as an assault on the reader's good faith" (36). Here, then, Amis's engagement with the crime thriller is seen as a violation of the literary fictionist's contractual obligations to the reader. There is also an illuminating transnational element to Brookner's attack, since she criticizes Amis for "going native so wholeheartedly that there is barely a trace of his literary origins" (37). In this sentence, the long history of association between the American vernacular and the literary from Mark Twain onwards is effectively repressed. In its narrative procedure, however, Night Train is criticized for failure to adhere to the rules of the crime thriller, an objection shared by John Updike in his scornful attack in The Sunday Times. Updike also objects to "the unmentionable way the plot proceeds. My trouble is with the solution of the mystery and the point of the book" (1). On these grounds, then, Night Train can be neither literary nor genre fiction, fulfilling the criteria of neither. Hybrids are not countenanced.

Brookner and Updike provide case studies in policing genre boundaries, even if, as we have noted, Updike later seemed to admit reluctantly that his own 
writing occupied a generic space alongside chick lit and spy thrillers. In Night Train's reviews, we are clearly a long way from the valorization of genre transgression proposed by several generations of Formalist critics in their theorization of literary evolution. As Tsvetan Todorov wrote in 1971: "detective fiction has its norms; to 'develop' them is also to disappoint them: to 'improve upon' detective fiction is to write 'literature, not detective fiction” (43). Rather than such dialectical engagements between high art and mass genres, we can now observe in the Anglo-American reviewing context a category of literary fiction confirmed in its own hermetically sealed realm above and beyond its populist rivals. Nevertheless, Amis's own literary strategies in composing Night Train owe much to the Formalist tradition. A minor indicator of this debt is to be found in his intertextual reference to Frank Kermode's classic study of narrative, The Sense of an Ending (1967), which itself draws on this same legacy in arguing that "however you put it, the history of the novel is one of forms rejected or modified, by parody, manifesto, neglect, as absurd" (129-30). The title of Kermode's book, which was seminal during the time Amis studied English literature at Oxford between 1968 and 1971, finds its way into Night Train as the title of a subsection in the second part of the novel. In Night Train, I will argue, Amis employs precisely this manoeuvre of superseding the modern crime narrative through deliberate engagement, in ways that are inimical to the contemporary category of literary fiction. In what follows, then, we turn to mapping Amis's narrative and stylistic strategies for accomplishing this.

\section{NARRATIVE GAMES}

As Updike's objection to the "unmentionable" plot of Night Train suggest, the novel presents a series of departures from the conventional crime narrative. Although it begins in the expected manner, with the discovery of a body, the chief driver of the plot is at first the attempt to prove that Jennifer's death was caused by murder rather than the suicide suggested by the evidence. "Bring me something I can live with," her father tells Mike, "because I can't live with this" (19). After the failure of this objective, the second part of Night Train finds detective Mike Hoolihan searching in desperation and futility for a suicide motive. The novel ends with Mike apparently contemplating her own suicide. Night Train creates its own poetics of self-destruction, which will demand further consideration, but for the moment we must begin with the methods Amis employs for manipulating the conventions of the classic detective narrative.

Franco Moretti, in his chapter on classic detective fiction in Signs Taken for Wonders (1983), takes up the question of the relationship between "literature" and "mass culture." In his formulation, detective fiction incorporates the narrative features conventionally associated with literature, but only insofar as they can produce the required distance and delay between the appearance of clues and their resolution into a revealed siuzhet. Thus, "literature is still desired but only to be mocked and relegated to useless memories" (149). Detective fiction's "distinctive 
feature" is then this fixed relationship between surface and depth, in which signs have a dual function of pertaining to both the everyday and to the clue that leads to the solution. Turning to Night Train, we find that the novel's narrative strategy destabilizes this duality in two ways. The first involves the removal of the secondary function, of revealed depth. Jennifer's boyfriend is witnessed leaving her apartment on the day of her death looking distressed. This particular clue is disclosed early in the narrative but its resolution is withheld until the closing pages, according to the classic formula. Rather than signifying an argument and thus a motive for murder, we discover that Trader's "distress" was the result of a comic series of physical mishaps - the snapping of a shoelace, the catching of a hangnail in a sock, the ripping of a coat pocket on a door-handle (131). Here quotidian contingency remains trivial, becoming meaningless at precisely the moment when it is burdened with the function of clue. On a grander scale, Jennifer's death is subjected to a comparable logic - the apparent suicide is not a mask for murder but is exactly as it seems. This, for her father as for us, is what cannot be lived with.

A more radical gesture is made by the second way of undermining the characteristic semantic duality of the clue. This is the removal of the first function, that of the quotidian. Once Night Train establishes itself as unaccommodating to the classic whodunit it transfers its loyalties towards the American noir structure, with its demands for motivational satisfaction located in the personal pasts of the characters. A second set of clues accordingly present themselves. Jennifer was taking anti-depressant medication and, despite being in a happy relationship with Trader, had arranged a date with a lecherous older man for an evening several weeks after her death. She even owned a book titled Making Sense of Suicide. It transpires, however, that these clues to her mental profile were set up by Jennifer herself, specifically as clues offering a pattern to explain her death. The medication was simply stolen from a friend who did have a mental illness. The date, which Mike Hoolihan attends in Jennifer's place, is in a bar called the Decoy Room. The day is April 1st. Clues are clues only when they are something else too-when they have a surface meaning to measure against, or to be superseded by, the buried one. Jennifer's black joke is also Amis's - to reverse the charge conventionally leveled at genre fiction. The second half of Night Train is all depth and no surface.

Such semantic collapse brings us to the dominant metaphors of the novel. Jennifer was an astrophysicist who spent much of her working life staring into black holes, and we are supposed to be doing much the same in negotiating this narrative, which gradually retreats from causation and approaches death as pure formal closure. "Suicide is the night train, speeding your way to darkness," Mike tells us, and the final pages indicate that she is headed the same way as Jennifer, unable to orientate herself within the semantic void she finds herself in (67). Amis's interest in suicide stems in part, as he has suggested, from biographical sources. Yet its function is not restricted to thematics, for Night Train enacts it at the level of form. ${ }^{5}$ The objective of detective fiction, as Moretti among others has pointed out, is the return to the beginning, and the associated restoration of the social order (137). Night Train clearly withholds this kind of endgame, and this 
is one of the crudest indications of its pretentions to legitimate itself beyond its genre. It would be a mistake, however, to ascribe such a structure to the clichés of postmodernist theory, in which the principle of relativism would ensure that "solutions" to the crime proliferate with abandon. There is no undecidability or indeterminacy here, but a single unambiguous solution, the all-embracing nihilism of suicide-as-joke. The act of self-destruction refers the exercise of power over the body back to questions of autonomy. We are invited to consider Jennifer's suicide allegorically in terms of literary form, an act of resistance to the restrictive tyranny of the detective form with its demands for logical solutions and other conventions. If Jennifer kills herself physically, then Night Train performs a narrative suicide. This in itself reflects Amis's own self-confessed contempt for plot as a concern he associates primarily with lower forms of fiction: in an interview about Night Train he confessed, "as someone writing for a so-called literary audience, I always rather despised plot" (Miller).

At this point, we need to return to the distinction between two categories with claims on Amis's fiction. These are contemporary literary fiction on one hand and an autonomous experimental tradition on the other. The former, marketed principally on the strength of its cultural legitimacy, is where Amis is located on the evidence of his publisher, his appearances on televised review programs and literary festivals, the regular coverage his novels receive from the "quality" press and so on. ${ }^{6}$ The self-destruction of form, however, recalls the trajectory of the postwar avant-garde as it developed from late modernism in the 1950s and "60s. Ihab Hassan, in The Dismemberment of Orpheus (1971), saw a "postmodern spirit" exemplified in the transition from Beckett's prose and John Cage's music of the early 1950s into the French nouveau roman of Robbe-Grillet and on into the fictions of John Barth and Nabokov in the 1960s. His terminology, in view of what followed (Jameson's work in particular), would now be widely disputed. ${ }^{7}$ More useful to us are the imagery and rhetoric he deploys in summarizing his analysis and their resonance with Night Train's dominant metaphors. "These experiments," he writes,

... tended towards vanishing forms. They carry intimations of silence, a consciousness spinning loose of history, trying to twist free of words and things. Drawn to a strange vision of itself, the imagination invades the void. But as Antonio Porchia, who knows little about the avant-garde and cares less, says: "The void terrifies you and you open your eyes wide." Wide-eyed, the postmodern spirit sees everything - or nothing. It sees, anyway, that violated being gives rise to the tragedy of literary forms, and dares to wish an end to outrage. (247)

The void that Hassan here associates with the postwar avant-garde's war against fictional form is, as we know, realized in Jennifer's academic interest in astrophysics, where "the seeing" refers to the quality of the image of the black skies, as well as in the imagery of the suicidal impulse as the night train. The affinity of Amis's fiction with this moment in the American academy should not surprise us. Hassan can be understood as part of a critical trend dominant in the 
late '60s and early'70s that lionized the achievements of an avant-garde in retreat from its most ambitious utopian objectives. Amis received his English degree from Oxford in 1971 and spent the 1970s in the world of literary journalism at The New Statesman and the TLS. This is when he developed his obsession with what he called the "black farces" of Vladimir Nabokov, who was the perhaps the clearest beneficiary of the American academic endorsement of formally self-conscious games playing. It is also no coincidence that three modern writers Hassan explicitly identifies with the "postmodern spirit" - Robbe-Grillet, Barth and Nabokov - all engaged, exploited and dismantled the detective genre themselves. The "outrage" perpetrated against the literary, and which necessitated formal revenge with increasing urgency in the postwar period, is none other than the incursions of mass culture into its own sacred cultural domain. The response is to reassert autonomy by subsuming its inevitable presence into the higher designs of the literary. In Amis's case this is attempted largely through style.

\section{GENERIC STYLE}

In 2003, Amis complained that:

no one wants to read a difficult literary novel or deal with a prose style which reminds them how thick they are. There's a push towards egalitarianism, making writing more chummy and interactive, instead of a higher voice, and that's what I go to literature for. (Muir)

To suggest that we can use narratology as a way of transforming Night Train from police procedural to avant-garde is to underestimate the ambivalence suffusing the hard-boiled voice in the novel. The need for a "higher voice" was articulated in relation to his badly-reviewed Yellow Dog, but how can we reconcile such unabashed elitism with the demotic tones of Mike Hoolihan? Amis's own reviews of genre fiction provide an interesting frame for this question, for, examining these, we discover that death in the detective genre is not only a structural principle but also a stylistic one. In reviewing Thomas Harris's 1999 detective-thriller, Hannibal, he wrote: "Hannibal is a genre novel, and all genre novels contain dead sentences. . . . Harris has become a serial murderer of English sentences and Hannibal is a necropolis of prose" (The War Against Cliché240). Amis is effectively paraphrasing Nabokov's writing on Ulysses in Lectures on Literature, as he does in his own essay on Joyce. ${ }^{8}$ In his lecture on the Nausicaa chapter of Joyce's Ulysses, Nabokov uses the same metaphors of death and decay to describe the operation of cliché:

When we say cliché, stereotype, trite pseudoelegant phrase, and so on, we imply, amongst other things that when used for the first time in literature the phrase was original and had a vivid meaning. In fact, it became hackneyed because its meaning was at first vivid and neat, and attractive, and so the phrase was used over and over 
again until it became a stereotype, a cliché. We can thus define clichés as bits of dead prose and of rotting poetry. (Lectures on Literature 346)

Nabokov is writing about genre too, describing the ladies-magazine prose that Joyce appropriates for this chapter. The important point for our own analysis is that Nabokov finds redemption for Joyce's stylistic choices in Nausicaa, for "Joyce cause $[\mathrm{s}]$ here and there some of that dead and rotting stuff to reveal its live source, its primary freshness" (346). Given Amis's evident interest in Nabokov's reading of Joyce, we may be tempted to suppose that he is attempting something similar in the American hardboiled vernacular employed in Night Train.

How are we able, then, to discern the difference between the dead, rotting necropolis of prose inherent in genre fiction and the "higher voice" that is able to recover authenticity in the most hackneyed style? As we saw from the very mixed reviews that greeted Night Train, we will see that several critics were quite unable to make such distinctions. This is partly because, unlike in many other Amis novels (London Fields, for example, which also proclaims itself "a murder story" [1]), there is no framing voice to contrast with. Rather, we have our hard-boiled detective installed at the very beginning:

I am a police. That may sound like an unusual statement - or an unusual construction. But it is a parlance we have. Among ourselves, we would never say I am a policewoman or I am a police officer. We would just say I am a police. I am a police and my name is detective Mike Hoolihan. (1)

The use of the phrase "I am a police" is lifted from David Simon's best-selling journalistic opus, Homicide: A Year on the Killing Streets (1991). ${ }^{9}$ Amis wrote about using this "cathedral of illumination" while researching American cop talk for Night Train in 1995. The value of Simon's work, he claimed, was the authenticity of the voices he uncovers: "It doesn't tell you how cops talk to outsiders, to poised microphones; it tells you how they talk to each other, and, by swift extension, how they talk to themselves" ("I wish I'd written"). This, then, is one way of approaching the question of how to avoid the necropolis of prose-by catching the rhythms and lexicon of genuine cop talk before they decay into genre writing.

From this perspective, Night Train adopts and distorts the narrative conventions of the hard-boiled procedural but offsets such knowing strategies through appeals to authenticity through style. This is more or less what Mike herself tells us when she berates the influence mass culture has had on the discourse of crime and policing:

$\mathrm{TV}$, etcetera, has had a terrible effect on perpetrators. It has given them style. And TV has ruined American juries forever. And American lawyers. But TV has also fucked up us police. No profession has been so massively fictionalized. I had a bunch of great lines ready. Like: I was quit when you came in here. I'm twice as quit now. But this was Colonel Tom I was talking to. So I spoke the plain truth. (19) 
We are reminded here of Baudrillard's well-known theorizing in his Simulacra and Simulation (1985) of a postmodernity governed entirely by pure simulation, in which the distinction between reference and reality is entirely effaced. ${ }^{10}$ In this passage, however, Amis appears to be reserving some small space still for authenticity of voice, in resistance to a hegemonic television culture. It is not the case, however, that Mike herself is immune to the operation of cliché, despite her best efforts. Having remarked on the fallacy of becoming sentimental about full moons ("not even Italian police get sentimental about full moons" [8]), she still notices, at the crime scene, Jennifer's eyes "still moist in the moonlight" (10). Not only are we presented with a voice fully aware of the threat posed by genre, we also see glimpses of submission to its power.

Some of the most complimentary reviews of Night Train attempted to retrieve Amis from the perceived vacuum of literary posthumanism by taking the pathos of which this an example to be the novel's most valuable feature. Adam Phillips, for instance, wrote of its ability to dramatize "language warding off the experience it describes" (6). Meanwhile, in the most sophisticated academic reading of Night Train, Gavin Keulks locates "Amis's swerve, or retreat, from radical postmodernism" in this same "mediated voice" ("W(h)ither postmodernism" 166). According to this view, we must understand Mike's voice not to represent a window onto some authentic self, but to be the means by which it protects itself from a corrosive and violent postmodernity. It is worth noting that the production of pathos through the juxtaposition of private suffering on one hand and its inadequate expression in the language of cliché is the second "more subtle" effect that Nabokov notes in Nausicaa (Lectures on Literature 347). Such humanist readings, which might pay attention to Mike's own abused childhood, as well as her constant exposure to extreme violence for the most trivial of reasons, are generally persuasive, as well as being comfortably compatible with the kind of endorsements required by the category of literary fiction. ${ }^{11}$ The "higher" voice is constituted here as a humanist resolution emerging from the putative encounter between authentic experience and the pervasive, debilitating effects of reified genre style.

There are problems with these readings, however, which are obliged to remain silent about a crucial element of Amis's aesthetics - the seductive pleasures offered by pure style. Returning to his reviews, we find that genre prose is not always bad. A particularly illuminating case is offered by his reception of veteran procedural writer Elmore Leonard, whose Riding the Rap was one of the "orgy of thrillers" that formed part of Amis's research for Night Train. ${ }^{12}$ He describes Leonard as "a literary genius who writes readable thrillers," and despite being called a "genre writer," Leonard "possesses gifts — of ear and eye, of timing and phrasing - which even the most snobbish masters of the mainstream must vigorously covet" (War Against Cliché 225). In an interview with Leonard on American television, Amis gave a name to this talent: "perfect pitch" ("A Conversation with Novelists"). The musical term employed here indicates the value placed on pure form free from the constraints of content (Flaubert's dream of the perfect book "about nothing"). Amis's review associates Leonard's musically accomplished 
style with the United States in particular, and with the cynically postmodernist character construction evident in his crime novels:

\begin{abstract}
"Dutch" Leonard is as American as Jazz, and jazz is in origin a naive form. Yet he is no Louis Armstrong. He can do melody, but he is also as harshly sophisticated as late-period Coleman Hawkins. He understands the post-modern world-the world of wised-up rabble and zero authenticity. His characters are equipped not with obligingly suggestive childhoods or case-histories, but with a cranial-jukebox of situation comedies and talk shows and advertising jingles, their dreams and dreads all mediated and secondhand. They are not lost souls or dead souls. Terrible and pitiable (and often downright endearing), they are simply junk souls: quarter-pounders, with cheese. (War Against Cliché 226)
\end{abstract}

This passage reflects compellingly back on Night Train in ways we need to consider if we are to understand Amis's uniquely ambivalent position in relation to literary fiction as it is constructed in the US and the UK respectively. Mike Hoolihan's own disclosure of childhood abuse is, of course, "obligingly suggestive," especially in the way it has facilitated the kind of humanist reading outlined above. Leonard's value inheres partly in his faithful representation of the postmodern world of "zero authenticity," precisely the world that, if we are to follow this reading, is subject to critique in Night Train. Furthermore, the jazz metaphor allows us finally to begin to conceptualize the relationship between mass culture and the avant-garde that has vexed the reception of Night Train.

The presumed naivety of Louis Armstrong carries with it the burden of the accusations leveled at him at the tail end of his career-of being unable or unwilling to leave behind the most popular jazz forms and of submission to the dictates of the culture industry at the cost of experimentalism. Coleman Hawkins, on the other hand, having learned from Armstrong's technique in the 1920s, went on to record one of the first recognized bebop sessions in 1944 and to develop a reputation based on individualism and innovation that resisted assimilation even into the radical modernism of Gillespie and Parker. The "harsh sophistication" of late Hawkins marks a point in US musical history where the American vernacular and the avant-garde meet, an encounter less easily located in modern British culture (we should also note that the transition from naivety to sophistication in both form and tone is the principal factor in the paradigm shift from the classic detective story into the hard-boiled fiction of Hammett and Chandler). ${ }^{13}$ Similarly, Leonard's "wised-up" prose must assimilate popular vernacularism but also self-consciously abstract it from its social premises, under the banner of style. This process of abstraction is greatly accentuated when we take into account our paratextual knowledge, achieved through Amis's celebrity within the literary establishment, of his own nationality and high-cultural status. Recalling Humbert Humbert in Lolita, he becomes the cultured European émigré in search of an essential naïve America that can be subjected to the calculated cruelties of style for the consumption of the educated reader. It is this, ultimately, that permits Amis's condescension towards the "junk souls" of the US masses. If 
Mike Hoolihan becomes merely "endearing," then the humanist reading of Night Train becomes very difficult to sustain.

We have been presented then with several ways of understanding the "higher voice" of Night Train. On one hand, there is the delicately balanced pathos of the authentic self struggling to penetrate the degraded genre discourses of postmodernity. On the other, there is the "wised-up" cynicism and perverse comedy of pure style, in which the crime genre is transformed into avant-garde through its exploitation as a means of accessing the linguistic playfulness and exuberance of the American vernacular. Bearing this ambivalence in mind, how are we to read a passage like this one?

So I've seen them all: Jumpers, stumpers, bleeders, floaters, poppers, bursters. I have seen the bodies of bludgeoned one-year-olds. I have seen the bodies of gang-raped nonagenarians. I have seen bodies left dead so long that your only shot at t.o.d. is to weigh the maggots. But of all the bodies I have ever seen, none has stayed with me, in my gut, like the body of Jennifer Rockwell. (4)

The shocking violence of the content owes much to David Simon's Homicide (the detail about the maggots, for example, is almost directly lifted [Homicide 66]). However, threatening to overcome the demands for authenticity and realism, the framing sentences pull in a different direction. The lexical catalogue in particular performs work characteristic of Amis's style by enacting the very process of subordinating the communicative function to self-conscious performance. The playfully alliterative qualities of the list and its grotesque, visceral comedy betray a guilty pleasure in transforming the violated body into an autonomous style held up for perverse admiration. The aestheticizing of the corpse, and indeed the form of the list itself, in which language petrifies and drifts from its referents, recalls the classic texts of nineteenth-century French decadence. ${ }^{14}$ Instead of the rarefied lexis of Huysmans, however, we are dealing with the vernacular of an American mass genre. Amis uses the term "post-modern decadence" (War Against Cliché 226) to describe the experience of reading Elmore Leonard, but it is equally apposite here.

\section{POSTMODERN DECADENCE}

The idea of postmodern decadence serves as an invitation to historicize Night Train in a certain way, and in this section I will explore some of the implications of that term for our understanding of the respective roles of genre and aesthetic autonomy in Amis's fiction. The late twentieth century, and the mid-1990s in particular, represent a moment when Amis's natural affinity with various decadent principles - the elevation of style over matter, the assumption of art as an autonomous cultural field, the appropriation of cruelty and irony in enforcing distance between the artist and the work and the reconfiguring of relations between nature and artifice - gained a kind of topical relevance because of the prominence of postmodern theory not only in the academy, but also in more mainstream public discourse. Thanks to its shared interest in such principles, the age 
of postmodernism allowed Amis to present a rather dated set of aesthetic ideals in a contemporary light and it was upon this that his reputation as enfant terrible of the British literary scene in the 1980s and '90s rested. (We might also add that the subsequent deterioration of his critical reputation has coincided with both his own turn to politics and the waning of popular interest in postmodernism in the first years of this millennium.)

We turn, then, to one of the novel's significant historical contexts, that of popular American cinema and television in the early to mid-1990s. Although the crime writing of Elmore Leonard and David Simon constitute points of reference for Night Train, we should not forget that it is cinema and television that provide the principal technological focus for Amis's Baudrillardian vision of postmodern simulation. In one episode, a potential witness is unable to distinguish between a "real" gunshot and one heard on a televised cop show (38). In another, Mike remarks on how local gangsters had inherited authentic mafia style not from their previous generation but from movies about the Italian mob (52). Only Mike herself, it seems, has the ability to differentiate between simulation and the real: "the homicide/suicide gray area is TV, is bullshit, is ketchup" (17). It is no coincidence that these examples all relate to violence, for during the years leading up to and including Night Train's composition a public debate emerged over the "new brutality" in popular American cinema, represented by filmmakers such as Martin Scorsese and Brian de Palma. At the centre of these debates was the writer and director Quentin Tarantino, whose films Reservoir Dogs (1992) and Pulp Fiction (1994) attracted enormous media interest, not only because of the excessive violence they portrayed, but also because of the way that violence was mediated through a stylized and ironic pastiche of cop and gangster genres. Tarantino became the focus of a debate about the problematic relationship between signs within the artwork and "the real" that rehearsed in a crude sense several of the concerns of contemporary postmodern theory.

On one hand, specialist critics tended to affirm the films' status within an autonomous aesthetic field by evaluating them, whether positively or not, in terms of their self-reflexivity, intertextual allusions and so forth. As one contemporary reviewer suggested, Tarantino's cinema was "a pristine reflection of its socioartistic climate ... as nonreferential to a reality outside itself as a (theoretically) mimetic work can be" (McKinney 20-21). By contrast, some journalists and commentators worried that the slick, comic violence might inspire vulnerable viewers to imitate art in life. This anxiety culminated in the media frenzy over Natural Born Killers (1994), a film directed by Oliver Stone from a script written by Tarantino, which prompted John Grisham to accuse it of directly motivating two murders in Mississippi in $1995 .{ }^{15} \mathrm{We}$ can see then that the failure to distinguish between the realms of nature and artifice, the concern that compelled the great narratives of decadent fiction, had resurfaced in the guise of an argument about the effects of popular cinema in the 1990s. ${ }^{16}$ It was a debate of which Amis was well aware. In 1995, the year in which he researched Night Train, he wrote that "I happen to like screen violence while steadily deploring its real-life counterpart. 
Moreover, I can tell the difference between the two. One is happening, one is not. One is earnest, one is play" ("Blown Away" 18). This would suggest that Amis enforced an uncomplicated boundary between the enjoyment of violence as aesthetic play and the social. However, his next sentence articulates the dilemma informing Night Train's stylistics: "But we inhabit the postmodern age, an age of mass susceptibility, in which image and reality strangely interact. This is now the most vulnerable area in the common mind."

This is an important statement in that it opens up a way of understanding postmodern decadence as two different modes of aesthetic apprehension applicable to the same artwork. The assumption (and it remains just that) made by Amis, as by Grisham, that among certain "susceptible" groups the portrayal of stylized violence may be confused with the real thing, echoes Bourdieu's analysis of the habitus, or governing taste, or the French working class in the 1960s and "70s. This popular mode, Bourdieu argues, is "based on the affirmation of the continuity between art and life" (xxvii), and is to be contrasted with the habitus of the bourgeois, a disinterested appreciation of pure form analogous to Amis's enjoyment of violence as play (xxv). We must note, however, that crucial to the idea of postmodern decadence is the way in which pleasure is gained through the assumption of superiority, that less sophisticated consumers have approached the work in more naïve ways. The decadence of this position, then, inheres in its parasitic feeding off the perceived misreadings or misapprehensions of others. In Riding the Rap, then, Elmore Leonard places allusive jokes for the benefit of the reader familiar with high culture, which remain inaccessible not only to the "junk souls" he depicts, but also, we may surmise, to a number of his fan base: "Who's Ezra Pound?' // Chip said, 'Ezra Pound,' stirring his drink then pausing. 'He was a heavyweight. Beat Joe Louis for the crown and then lost it to Marciano. Or was it Jersey Joe Walcott?”' (79). Postmodern decadence, in addressing itself to several groups in different registers, thus presents acute difficulties for the marketing and distribution of literary fiction, which requires for its legitimacy uncomplicated assurances of its distance and distinction from mass genres and their readers. The constant danger of mistaking pulp for highbrow and vice versa, as we saw in the examples of Night Train's reception, is both the guarantee that the work demands highly refined judgment and the reason why it will be forsaken for less risky investments of cultural capital. This is the essential logic behind the increasing resemblance between the categories of literary fiction and the middlebrow, which I will return to later.

Meanwhile, in order to be able to situate Amis historically we must consider the forms of cultural temporality that postmodern decadence indicates. While these two parts of this term are popularly supposed to share a number of concerns - the privileging of artifice over the natural; irony and skepticism over the Romantic naïve and so forth - most pertinent to our discussion is their problematic relationship with the notion of cultural evolution. ${ }^{17}$ Decadence and postmodernism are, in their different ways, essentially futureless. While the decadent text represents writing on the brink of decline, feeding off the demise of its 
own culture, the postmodern one is unable to envisage a writing that might evolve beyond itself, since, according to the critical orthodoxy at least, in postmodernity "from the vantage point of change it becomes impossible to distinguish space from time" (Jameson 9). If decadence presupposes a historical end, the postmodernism of thinkers such as Fukuyama assumes an end to history. It is characteristic of Amis's consciousness to combine elements of both, by taking the cultural manifestations of postmodernity (the proliferation of mass generic simulation at the cost of the real) as either symptoms of, or correlatives to, approaching termini. These ends are most commonly understood as historical destruction, and Amis's recurrent interest in nuclear destruction, the Jewish Holocaust and more recently the $9 / 11$ attacks is evidenced throughout his oeuvre. Night Train, in its thematic engagements with black holes and gravity, contributes another, astronomical scale to this structure. ${ }^{18}$ In addition, though, there is an important ethical dimension to Amis's sense of limit in which, as he once put it, "motivation" becomes a "shagged out force" (Haffenden 5). This is neatly translated into the terminology of the criminal investigation in Night Train, forming the impulse behind its perverse plot: as Mike tells us, "Motive might have been ... . in okay shape half a century ago. But now it's all in the fucking air" (107). According to decadence principles then, Amis's fiction can be said to feed parasitically on such human degradations, and to transform cultural decline into an aesthetic event while accelerating its course. Vampire-like, his writing appropriates and drains the energies of the social, gaining vitality in the same proportion as society decays ${ }^{19}$ From this perspective, he is not a postmodern writer so much as one who exploits the conditions of postmodernity for decadent aesthetics, while society itself falls victim to the endless play of simulation. ${ }^{20}$

All of this has significant implications for our understanding of Night Train's engagement with the mass genre of modern crime fiction. The development of crime fiction, as we discover from Amis's writing on Raymond Chandler, is accorded a particularly close relationship with historical time:

\footnotetext{
Sin, it would seem, has come a long way since 1939. So has profanity, and the general sense of crime. The underworld advances more quickly, and dates fester, than the overworld. As a result, Chandler's heavies just aren't heavy; his mean streets are clean streets - they are positively Arcadian. (War Against Cliché 216)
}

Here we see that Amis understands ethical deterioration to form an inevitable component of historical "advance" and find evidence of a crude historicism that requires that genres be updated if they are to retain their value. Put bluntly, the old-fashioned hard-boiled mystery just isn't equipped to deal with the contemporary moment. This is a position reflected in Amis's admiration for the crime novelist James Ellroy, whom he calls "the poet laureate of noir" ("I Wish I'd Written”). Ellroy himself expressed similar sentiments about the need for generic innovation in order to retain relevance, moving away from "the private eye tradition which formally jazzed me" towards the procedural, "the real goods at the gate" (qtd. in Fellows, Without Walls). While Amis finds Chandler's mean streets 
to be Arcadian, Ellroy describes the private eye form as "an iconic totem spawned by pure fiction, romantic moonshine" (qtd. in Without Walls). Accordingly, in his memoir My Dark Places, identified by Amis as another part of his research for Night Train, he adopts an idiosyncratically pessimistic vision of modern American crime deliberately emptied of that romance:

He learned some things about murder early on. He learned that men killed with less provocation than women. Men killed because they were drunk, stoned and pissed off. Men killed for money. Men killed because other men made them feel like sissies. (169)

Night Train's debt to Ellroy is that it consciously takes such extremes for granted. Towards the end of the novel Mike muses on murders committed over diapers, Christmas-tree decorations and rancid milk: "Downward disparity has already been plumbed - been sonar-ed and scoured. People have already been murdered for nothing. They cross the street to murder for nothing" (128). The literary formal implications of this are evident in Mike's remark that "homicide can't change . . . there's nowhere for murder to go. But what if suicide could change?"(129). Only unmotivated suicide, runs Mike's logic, can constitute an escalation in historically-determined ethical deprivation.

This is what brings about Night Train's status as a detective story facing a formal impasse in the dialectic between its generic form and history, left without murder, crime or motivation. We are returned once more to the way this novel invites us to think about form itself in terms of decline and endings, narrative suicides. In this sense, Night Train is an unrepeatable performance of limits, the final mutation that kills off a genre at the end of its evolutionary life. At the same time, however, the act of self-destruction remains a kind of Pyrrhic victory, a gesture of renunciation and refusal that gestures towards its elevation into the realm of a historyless, autonomous aesthetic even as it acknowledges its bond to popular fiction.

\section{NIGHT TRAIN AND LITERARY FICTION}

This binary of the unique and the repeatable returns us to the category of literary fiction in its relationship to mass genres. As Rachel Malik has pointed out,

Built into the literary as a category is the axiom that the literary text is highly individual, even unique - which, on the surface at least, is at odds with the patterns of textual resemblance on which marketing and promotion are conventionally dependent. (729)

Viewed from the perspective of our present discussion, Night Train's generic strategy suggests that it may nonetheless perform as literary fiction as well as crime novel (its publisher in the US currently lists it as both). At the level of plot, its conclusion, and in particular the suggestion of Hoolihan's own suicide outside the narrative boundaries of the text, ensures that it cannot be serialized. 
The evidence of Amis's oeuvre as it stands in 2011 tells us that Night Train was a singular experiment with crime writing. Once we bring questions of marketing and promotion into play, however, it becomes clear that publishers of literary fiction have used author branding as a means of replacing genre's function in the serialization process. Thus Vintage in 1999 included Night Train in their newly repackaged Amis series, which featured a newly coherent design theme. Within these parameters, the new edition moved away from their earlier cover, which unambiguously signified the crime genre by displaying an X-rayed pistol, towards the more nebulous connotations of a smoldering cigarette sketched in pencil. The new design was comfortably placed alongside other items in Amis's back catalogue, each with its similarly-styled object (London Fields's tower block, Money's airplane window), chosen in order to effect the maximum distance between the novels and genre fiction, as if to guarantee literary fiction's existence outside such spheres. The relative absence, or at least irrelevance, of cigarettes in Night Train is then a small measure of the compromises encountered in enforcing some kind of consistency between the novel's composition and its marketing.

The substitution of author branding for conventional genre signifiers in the marketing process is becoming increasingly common practice as authors, publishers, agents and booksellers fall back on celebrity as one of their chief resources. We are now invited to judge authors of literary fiction holistically in terms of their oeuvre rather to judge individual genre choices. While Amis's hero Nabokov, who consciously appropriated genres ranging from the literary biography to the spy thriller, provides an obvious literary correlative, we can observe similar processes at work in the career and marketing of the iconic auteur Stanley Kubrick. ${ }^{21}$ Kubrick's generic range matches even Nabokov's, as does his cultural authority. In this case, the recent popularity of the DVD box set fulfills the function of the thematically-designed book series. Pushing our comparison further, we can see that in all three cases aesthetic style itself, conceived as the mark of individual autonomy asserting itself over the demands of generic conformity, is the underlying justification for such author branding. The Amis style, in its characteristic tics such as phrase repetition and reiteration, the list and so forth, is recognizable through Mike Hoolihan's hardboiled voice, just as the symmetries of Kubrick's geometrical frame composition announce themselves in all his mature work, whether historical epic, erotic thriller or horror. This is where the rhetoric of the unrepeatable breaks down to reveal homologies at the level of style that stand as publically inadmissible to the category of literary fiction.

In order, finally, to situate Amis within the cultural field, we need to revisit Bourdieu's analysis and the historical shifts that have occurred since his insistence on aesthetic autonomy and disinterested apprehension as the markers of authentic cultural legitimacy. As James English has pointed out in his study of literary prizes, the dualist structure outlined by Bourdieu, formed by the absolute renunciation by autonomous artists of both commerce and social utility, and dominant since the end of the nineteenth century, began to disintegrate in the Anglo-American context during the late 1970s and early 1980s (The Economy of 
Prestige 220). This is not to say the old duality has disappeared, for literary fiction still demands to some extent the maintenance of fictions such as the reverseeconomic principle that "serious" writers are uninterested in commercial success, as we saw in the case of the outrage provoked by Amis's negotiated advance for The Information. While this economic shift remains taboo, the demands for legitimate culture to engage responsibly with the social sphere, and in particular to represent various ethnic and minority groups, are more or less overt. ${ }^{22}$ Amis's own prize scandal came in the 1989 Booker Prize in the UK, when London Fields, his longest and most technically ambitious novel, was overlooked for the shortlist on the grounds of its possible misogyny (Todd 85). ${ }^{23}$ The casual racism of Mike Hoolihan, which is construed through terms borrowed from David Simon for referring to African Americans (“jig," "yo"), would perhaps have been attributed to Amis in the same way, had Night Train been seriously considered for any of the major prizes. The problem revealed here once again hinges on the problem of anxiety over misreading and misrecognition. Accusations of complicity with misogyny and other transgressions levelled against Amis are made possible by the same aesthetic distance and posture of neutrality that previously served as a marker of cultural legitimacy dating back to Flaubert and Baudelaire in the nineteenth century.

As scholars are beginning now to interrogate the contemporary publishing category of literary fiction along with the various practices and processes associated with it, the territory it shares with the construction of middlebrow is becoming increasingly clear. ${ }^{24}$ The embarrassment this entails is perhaps best represented by Jonathan Franzen's well-known encounter in 2001 with the institution of Oprah's Book Club, as recently discussed by Evan Brier (156-64). Franzen, who described himself as "solidly in the high-art literary tradition" (157) expressed reluctance to participate in the great representative of American middlebrow taste, a strategy that was publically received in terms of ill-judged elitism, and that diminished rather than enhanced his symbolic capital. The awkward entreaties, refusals and withdrawals that characterized this illuminating episode are symptomatic of a transitional period during which the "rules" of the game were changing, yet various players remained unwilling or unable to adapt their own performance.

The postmodern decadence of Night Train, in exploiting mass culture for the purposes of high art, can be understood as another calculated move in the "culture game" during this same period of transition. The exclusion of the middlebrow effected by the generic and stylistic choices Amis made entered into conflict with the processes and practices by which the novel was circulated and consumed as contemporary literary fiction. In particular, the anxieties provoked among its reviewers over the dangers of misreading the distinction between high and low and thereby rendering one's own judgment vulnerable to ridicule disrupted the functioning of authoritative public endorsements so integral to the production of the category. The "success" of Amis's move is difficult to determine, since it hinges partly on the question of intention, whether or not such disruptions were a heroic, if futile, repudiation of the game itself or simply another misjudgment 
of the shifting criteria for cultural legitimacy. It is less disputable, however, that the exclusion of the middlebrow was entirely deliberate. This is evident in Amis's essay on Brian de Palma for Vanity Fair, where he applauded the director's lack of a middlebrow following and concluded that "it is an achievement of a kind, to fashion an art which appeals to the purist, the hooligan, and no one else" (Moronic Inferno 88). We are reminded here of the pun on Mike Hoolihan's name, and the way her vernacular rhythms, rough talk and cursing evoked such horror among several of Night Train's reviewers.

This perversely productive dialectic between the purist and the hooligan that directs itself against the middlebrow has several precedents in late modernism. It is visible, for example, in Virginia Woolf's assertion in her 1942 essay "Middlebrow" of a covert alliance of high and low, a "blood brotherhood against the bloodless and pernicious pest who comes between them" (184). ${ }^{25}$ An even closer correlative to Amis's position is found in Nabokov's The Real Life of Sebastian Knight, published the preceding year, where the eponymous novelist reveals "the dark secret" of his rival's success:

which is to travel second class with a first class ticket - or if my simile is not sufficiently clear - to pamper the taste of the worst category of the reading public — not those who revel in detective yarns, bless their poor souls - but those who buy the worst banalities because they have been shaken up in a modern way with a dash of Freud or "stream of consciousness" or whatnot. (46)

Fifty-six years later, this logic became the structural principle upon which Night Train was founded. In the era of literary fiction's hold over cultural legitimacy, however, such posturings no longer accrue symbolic capital. Thus Amis emerges as an intriguingly conflicted figure, hypnotized by his sense of the contemporary historical moment and yet profoundly untimely in his sense of the cultural field.

\section{Notes}

1. Qtd. in Grossman.

2. Here, as later in this essay, I draw on Rachel Malik's 2008 article "Horizons of the Publishable: Publishing in/as Literary Studies," which builds a case for placing at the center of literary studies the notion of publishing as a set of processes and practices, "constitutive of all formations of writing and reading" (707). Publishing thus includes the composition of the text as just one process intersecting with, and potentially conflicting with, others such as design, marketing and distribution. In this sense, literary fiction is a contemporary category constituted by a distinctive set of such processes and practices (725). It is notable that Malik's understanding of a "publishing category" in several respects resembles contemporary theorizations of the notion of genre by Bennett, Frow and others, who have stressed the way in which genres are constructed through what Bennett calls "reader formation," the institutional systems by which readers are led to expect, delimit and evaluate generic conventions (105). In both cases, the category or genre is constructed through historical variable processes and mediated through particular institutions, rather than inhering in the text itself.

3. Updike's disparaging comments, suggestive of an understanding of literary fiction as publishing category in the sense outlined above, can be contrasted to James Wood's use of the term in his 
review of Night Train, which concedes shared territory between genre and literary fiction, while still preserving a hierarchy: "all fictions are genres, but some genres are simply bigger and wiser than others; the noir is a passport photo to the literary novel's family portrait."

4. Keulks ("W(h)ither"165) also notes this source. The Sense of an Ending is an extended meditation on humans' need for narrative coherence: "to make sense of their span they need fictive concords with origins and ends, such as give meaning to lives and to poems" (7). Night Train uses the framework of the detective story to consciously address this need, but also to play out the consequences of its frustration.

5. See Amis's autobiographical Experience (280-82) for his ambivalent reflections on writing and suicide: "it awakens terror and pity in me, yet it compels me, it compels my writing hand" (280).

6. Vintage Publishing, Amis's publisher, describes itself as focusing on "quality literary fiction" (Vintage Books website). Part of the international Random House group, including imprints such as Jonathan Cape and Picador, Vintage published five Booker Prize winners since 1995, the clearest possible indication of its key role in the construction and maintenance of literary fiction in the UK. Its US list includes high-prestige, prize-winning novelists such as Toni Morrison and Philip Roth.

7. Connor (109-14) and Bertens (39-41) suggest some of the confusions arising from Hassan's construction of a non-periodized postmodernism that "lies coiled within the great corpus of modernism" (Hassan 139).

8. Amis's own essay on Ulysses collected in The War Against Cliché knowingly follows and elaborates on Nabokov's lecture and in particular his admiration of Joyce's dealings with cliché.

9. Night Train's specific debts to Homicide are too numerous to list here, but include various informal lexical items, such as "the show" to refer to homicide investigation (Night Train 3; Homicide 17), and the incorporation of particular procedures into the plot, such as the use of unfamiliar police jargon (e.g., "neutron-testing") as a method for intimidating suspects into confession (Night Train 56; Homicide 10). Homicide was adapted into the television series Homicide: Life on the Street, which ran in the US on NBC from 1993 to 1999, providing one explanation for why critics such as Walter and Piatek identify Hoolihan's voice primarily with television.

10. As others have noted (see Brook; Menke; Keulks "W(h)ither"), Amis's conception of postmodernity is a striking, if crude, reflection of Baudrillard's.

11. See, for example, Martinez-Alfaro; Kermode.

12. "Two summers ago, on the beaches of Long Island, I was able to look up from the latest Elmore Leonard with the vexed frown of the pious scholar - for I was hard at work: I was researching noir and US criminal justice. I was researching cops and robbers" ("I Wish I'd Written").

13. Amis may be recalling the commentary offered by his father's great friend, Philip Larkin, on Hawkins's 1961 album "Night Hawk," in which he "came back to a harsher, more direct manner without abandoning any of his middle-period complexities" (201).

14. On the aestheticization of the corpse in nineteenth-century French decadence, see Weir; Bernheimer. Nicholls (46-60) summarizes and discusses the classic theorists of decadent style, including Bourget, Gautier and Eliot.

15. Grønstad (155-56) summarizes the objections to Tarantino's aesthetics of ultraviolence. Grisham's polemic and Oliver Stone's response are collected in French.

16. Key examples of decadent fiction include Flaubert's Madame Bovary (1856), Huysmans's A rebours (1884) and Wilde's The Picture of Dorian Grey (1890).

17. Such oppositions are constantly recurring features of the many attempts to define decadence. David Weir provides a useful survey of how the term has been conceptualized, as well as an attempt to formulate a comparative perspective on decadence and postmodernism (1-21, 192-203). 
18. As Finney points out, astrophysics has also been used as a trope for what is happening for Amis's characters in London Fields and The Information.

19. I am adapting this vampiric metaphor from Nicholls's discussion of decadence and the human body (52).

20. See Keulks "W(h)ither Postmodernism" for a variety of positions on Amis and postmodernism. The critical tendency here is to construct a postmodernism encompassing Amis's writing practice rather than to understand him as I do, as a novelist responding historically to the conditions of postmodernity.

21. In Nabokov's 1940s fiction, The Real Life of Sebastian Knight (1941) stages the transformation of literary biography into modernist fiction, while Bend Sinister (1947) engages with the popular genre of the dystopian novel. Thereafter Nabokov begins to experiment with generic hybrids: Lolita (1955) blends erotic confession, road narrative and case history; Pale Fire (1962) is spy-thriller and academic edition; $A d a(1969)$ is sentimental novel and mémoire. Kubrick's generic range in his mature work includes, for example, science fiction (2001: A Space Odyssey, 1968), the dystopia (A Clockwork Orange, 1971), horror (The Shining, 1980), Vietnam film (Full Metal Jacket, 1987) and erotic thriller (Eyes Wide Shut, 1999).

22. As seen, for example, in the public lobbying for Toni Morrison's Beloved to win the Pulitzer in 1987 (discussed by English in The Economy of Prestige 237-45) or the dramatic successes of AngloIndian novels among literary prizes since Salman Rushdie's Midnight's Children (1981).

23. Amis's lack of recognition by the major literary prizes is matched by Nabokov's. Similarly, despite high prestige among peers and critics, Kubrick was never awarded an Oscar by the American Academy of Motion Picture Arts and Sciences.

24. Malik, for example, identifies the need for cultural intermediaries to intervene and delimit the parameters within which discussion of literary fiction can take place as a classical sign of the middlebrow as elucidated by Janice Radway (730). English, meanwhile, describes how producers of legitimate culture are now able to participate openly in the pursuit of symbolic profits once associated with the middlebrow ("Winning the Culture Game" 126).

25. Despite Woolf's early reflections, the consumption and theorizing of "the middlebrow" took place principally in the US during the mid-twentieth century. For an account and analysis of its development see Radway; Rubin.

\section{Works Cited}

Amis, Martin. "Blown Away." French 12-19.

—. Experience. London: Jonathan Cape, 2000. Print.

“I Wish I'd Written.” Guardian 2 Oct. 1997: 18. Print.

London Fields. 1989. London: Penguin, 1990. Print.

The Moronic Inferno and Other Visits to America. London: Penguin, 1987. Print.

Night Train. 1997. London: Vintage, 1998. Print.

The War Against Cliché: Essays and Reviews 1971-2000. London: Jonathan Cape, 2001. Print.

Bennett, Tony. Outside Literature. London: Routledge, 1990. Print.

Bernheimer, Charles. Decadent Subjects: The Idea of Decadence in Art, Literature, Philosophy and Culture in the Fin de Siècle in Europe. Baltimore: Johns Hopkins UP, 2002. Print.

Bertens, Hans. The Idea of the Postmodern: A History. London: Routledge, 1995. Print. 
Bourdieu, Pierre. Distinction: A Social Critique of the Judgement of Taste. Trans. Richard Nice. 1984. Intro. Tony Bennett. London: Routledge, 2010. Print.

Brier, Evan. A Novel Marketplace: Mass Culture, the Book Trade and Postwar American Fiction. Philadelphia: U of Pennsylvania P, 2009. Print.

Brookner, Anita. "Farewell, My Lovely." Rev. of Night Train by Martin Amis. Spectator 27 Sept. 1997: 36-37. Print.

Brook, Susan. “The Female Form, Sublimation and Nicola Six.” Keulks 87-100.

Connor, Stephen. Postmodern Culture: An Introduction to Theories of the Contemporary. Oxford: Blackwell, 1989. Print.

"A Conversation with Novelists Elmore Leonard and Martin Amis." The Charlie Rose Show. 17 Feb. 1999. PBS. Web. 12 Jul. 2010. <http://www.charlierose.com/view/interview/4439>.

Ellroy, James. My Dark Places: An L.A. Crime Memoir. 1996. London: Arrow, 1997. Print.

English, James. The Economy of Prestige:Prizes, Awards and the Circulation of Cultural Value. Cambridge, MA: Harvard UP, 2005. Print.

_ . "Winning the Culture Game: Prizes, Awards and the Rules of Art." New Literary History 33.1 (2002): 109-35. Print.

Fellows, Simon, dir. Without Walls: Good Ideas of the Twentieth Century: The American Cop. Feat. James Ellroy. Kudos Productions, 1994. Film.

Finney, Brian. Martin Amis. London: Routledge, 2008. Print.

Fischer, Tibor. "Someone needs to have a word with Amis." The Telegraph 4 Aug. 2003. Web. 21 Jan. 2011. <http:/www.telegraph.co.uk/comment/personal-view/3594613/Someone-needs-to-havea-word-with-Amis.html>.

French, Karl, ed. Screen Violence. London: Bloomsbury, 1996. Print.

Frow, John. Genre. London: Routledge, 2006. Print.

Grønstadt, Asbjørn. Transfigurations: Violence, Death and Masculinity in American Cinema. Amsterdam: Amsterdam UP, 2008. Print.

Grossman, Lev. “John Updike, Literary Heavyweight.” Time 27 Jan. 2009. Web. 13 Jul. 2010. <http:// www.time.com/time/arts/article/0,8599,1874276,00.html>.

Haffenden, John. Novelists in Interview. London: Methuen, 1985. Print.

Hassan, Ihab. The Dismemberment of Orpheus: Towards a Postmodern Literature. New York: Oxford UP, 1971. Print.

"I'm looking for some money." The Sunday Times 8 Jan. 1995. Web. 9 Jul. 2010. <http://www .martinamisweb.com/documents/looking_for_money.doc>.

Jameson, Fredric. The Seeds of Time: The Wellek Lectures at the University of California, Irvine. New York: Columbia UP, 1994. Print.

Kakutani, Michiko. “Detective Mike Hoolihan? She's Tough.” Rev. of Night Train by Martin Amis. New York Times Jan 27 1998: E7. Print.

Kermode, Frank. The Sense of an Ending: Studies in the Theory of Fiction. Oxford: Oxford UP, 1966. Print.

Keulks, Gavin, ed. Martin Amis: Postmodernism and Beyond. Houndmills: Palgrave, 2006. Print.

.W(h)ither Postmodernism: Late Amis.” Keulks 158-79.

Lanchester, John. “Death Becomes Her." Rev. of Night Train by Martin Amis. The New Yorker 16 Feb. 1998: 80-81. Print. 
Larkin, Philip. All What Jazz: A Record Diary. London: Faber, 1970. Print.

Leonard, Elmore. Riding the Rap. 1995. London: Penguin, 1996. Print.

Lyall, Sarah. "Martin Amis' Big Deal Leaves Literati Fuming." The New York Times 31 Jan. 1995. Web. 21 Jun. 2010. <http://www.nytimes.com/books/98/02/01/home/amis-bigdeal.html>.

Malik, Rachel. "Horizons of the Publishable: Publishing in/ as Literary Studies." English Literary History 75.3 (2008): 707-35. Print.

Martinez-Alfaro, Maria Jesús. "A Look into the Abyss: The Unsolvable Enigma of the Self and the Challenges of Metaphysical Detection in Martin Amis' Night Train." Journal of Narrative Theory 40.1 (2010): 108-28. Print.

McKinney, Devin. “Violence: The Strong and the Weak." Film Quarterly 46.4 (1993): 16-22.

Menke, Richard. "Mimesis and Informatics in The Information." Keulks 137-57.

Miller, Laura. "The Sadistic Muse." Salon 10 Feb. 1998. Web. 21 Jan. 2011. <http://www.salon.com/ books/int/1998/02/10/cov_si_10int/index.html>.

Muir, Kate. "Amis Needs a Drink." The Times 13 Sep. 2003. Web. 1 Mar. 2011. <http://www .martinamisweb.com/interviews_files/muir_interview.pdf>.

Nabokov, Vladimir. Lectures on Literature. Ed. Fredson Bowers. San Diego: Harcourt Brace, 1982. Print.

- The Real Life of Sebastian Knight. 1941. Afterword by John Lanchester. London: Penguin, 2001. Print.

Nicholls, Peter. Modernisms: A Literary Guide. 1995. 2nd ed. Houndmills: Palgrave Macmillan, 2009. Print.

O'Brien, Geoffrey. "The Big Sleep." Rev. of Night Train by Martin Amis. The New Republic 11 Sept. 1998: 32-35. Print.

Piatek, Beata. "Bullshit TV Conversations' or Intertextuality in Night Train." Homo Narrans: Texts and Essays in Honor of Jerome Klinkowitz. Cracow: Jagiellonian UP, 2004. 157-74. Print.

Phillips, Adam. "Cloud Cover." Rev. of Night Train by Martin Amis. London Review of Books 16 Oct. 1997: 3, 6-7. Print.

Radway,Janice A. A Feeling for Books: The Book-of-the-Month Club, Literary Taste and Middle-Class Desire. Chapel Hill: U of North Carolina P, 1997. Print.

Rubin,Joan Shelley. The Making of Middlebrow Culture. Chapel Hill: U of North Carolina P, 1995. Print.

Simon, David. Homicide: A Year on the Killing Streets. New York: Ballantine, 1991. Print.

Todd, Richard. Consuming Fictions: The Booker Prize and Fiction in Britain Today. London: Bloomsbury, 1996. Print.

Todorov, Tsvetan. The Poetics of Prose. Trans. Richard Howard. Ithaca, NY: Cornell UP, 1977. Print.

Updike, John. “It's a Fair Cop.” Rev. of Night Train by Martin Amis. Sunday Times Books 21 Sept. 1997: 1-2. Print.

Vintage Books. Web. 21 Jan. 2011. <www.vintage-books.co.uk>.

Walter, Natasha. "If you have tears to shed, be prepared to shed them - in a Martin Amis novel." Rev. of Night Train by Martin Amis.The Guardian 11 Sept. 1997. Web. 13 Jul. 2010. <http://www .guardian.co.uk/books/1997/sep/11/fiction.martinamis>.

Wood, James. "An American in Amis." Rev. of Night Train by Martin Amis. The Observer Review 21 Sept. 1997: 17. Print.

Woolf, Virginia. "Middlebrow." The Death of the Moth. New York: Harcourt Brace, 1942. 176-86. Print. 